\title{
'Keeping it real': the politics of Channel 4's multiculturalism, mainstreaming and mandates
}

\section{Sarita Malik}

Email: Sarita.Malik@brunel.ac.uk

When Channel 4 decided how it was going to fill what was described in the Annan Report as 'the empty room of British broadcasting', it was agreed that Britain's Africans, Caribbeans and Asians were to be important residents. This was meaningful for Channel 4 because it was tasked with providing what Stephen Lambert then described as 'opportunities for talents which had previously not been fully served' and with serving needs 'which have not been fully defined'. [1]

And yet the recent history of the channel has been characterized by the closing stages of a particular kind of 'public service' approach; one in which ethnic minorities have become simultaneously integrated in and disconnected from mainstream output in distinct ways. Twenty-five years on, the channel is caught up in the difficulties facing the structuring of public service broadcasting and in the challenges posed by the highly contentious politics of recognition for the settlement of the relation between a variety of social rights. On the one hand, black and Asian Britons, who as part of the postcolonial phase of migration to the UK might be regarded as the 'old ethnics', do not now appear to be a priority for Channel 4. On the other, the legacy of the relationship between Channel 4, these communities and broader ideals of 'multiculturalism' appears to be strong, not least according to the channel's current claims.

The channel's most recent cultural diversity statement says that 'Multicultural programmes remain at the heart of Channel 4's 2007 schedule', and in a summary of its Race Equality Scheme, Channel 4 states its ongoing commitment. In public discourse, therefore, the channel is keen to emphasize continuity over change. Strategically this is important because the ideology of 'multiculturalism' has always been a significant aspect of the channel's branding: a nod to the fact that the channel is publicly accountable in a unique way and that it is the champion of otherwise unheard, marginalized or misrepresented voices. Cultural diversity is, of course also a key facet of the liberal project.

But Channel 4's relationship with ethnic minorities has not been uncontested, static or fixed. Change has occurred on several fronts, but chiefly in two areas. First, in its approach to representation; changes have occurred against a broader sociopolitical backdrop in which definitions and attitudes towards the idea of 'multiculturalism' have altered and also lost favour. Second, in its relationship with key stakeholders, including the public and its product-suppliers. Amongst these are black independent producers who do not feature heavily in the channel's list of 'preferred suppliers', the larger, trusted companies that began to dominate in the 1990s. Both these areas have been heavily shaped by an increasingly competitive marketplace which has undermined many of the values of Channel 4's original remit and, to a certain extent, the public's trust in the channel. The path of such developments has involved investment and disinvestment, transparency and duplicity, and a trajectory that can most straightforwardly be described as moving from the radical to the conventional. The 'duty to be different' has therefore been challenged both by intensifying market competition and the broader political emphasis on the 'duty to integrate'. [2]

Historical background is important, as it underpins the relationship between Channel 4 and Britain's black and Asian communities. Channel 4, as part of a broader regime of cultural governance, positively acknowledged Britain's multicultural lived experience in both representation and structure. It became what might be called a 'multicultural public 
sphere'. Channel 4 had been campaigned for by those who realized the importance of introducing a third space to the BBC and ITV duopoly. For many minority groups, this new home was a direct result of the unprecedented degree of pressure placed on state institutions to alleviate discrimination and disadvantage. Ethnic minorities, along with women and youth audiences, represented the Channel's principal target groups in its remit to cater for distinct and neglected audiences.

Channel 4's core objectives, like the founding principles of UK public service broadcasting, were not based exclusively on market share but on providing programmes that large sections of the public often did not really want to watch. Moreover, Channel 4 's cultural-political agenda was even more explicit than the BBC's, which had typically adopted a more broad-based, conservative approach to what constitutes 'multiculture'. By contrast, and essentially because of the moment in which it was born, Channel 4's characterization of 'diversity' was as something edgy, modern, fluid and decentred. During the 1970s and 1980s, the shift towards practical strategies of antiracism positive action, ethnic minority inclusion and contract compliance - to which Channel 4 contributed, was implemented as a tougher and more direct intervention to enable social change than the ideological struggle for 'multiculturalism'. I deas filtering through from the New Left provided a justification for resisting the simple ambition to assimilate.

The 1980s was 'a critical decade'[3] both because of the emergence of this cultural space under the management of the channel's first chief executive, Jeremy Isaacs, and because it was the moment in which the public debate about race relations opened up. Many of those who pushed issues of 'race' onto the agenda of British television came largely from outside the broadcasting institutions, which were still predominantly whiteled and focused in terms of content and address. Amid such developments, the audiovisual space for Britain's emerging independent sector was being redefined. The lobbying and debates about training and access for Britain's black cultural workers helped to prepare the ground for the formation of Channel 4. The channel's commitment to 'say new things in new ways', its minority-based rationale formally inscribed in a Multicultural Programmes Department, along with its commitment to independent filmmaking, meant that it could offer a new form of cultural support to black British film and programme-makers. This included the emergence of independent production companies commissioned to work on individual projects but also the grant-aided workshop sector, a space in which collectives could produce relatively small-scale, innovative and experimental films.

This support and general agreements about pay negotiated with ACTT (Association of Cinematograph, Television and Allied Technicians) meant that such groups could avoid the constraints of commercialism and the logic of the marketplace.[4] There was also, however, a large amount of dependency involved in such arrangements, with no reciprocal guarantees for producers. But Channel 4 as publisher/broadcaster had a distinct structural advantage by being able to tap into new and often untested talent. Creatively, a certain cultural energy and distinctiveness was also recognized as emerging from 'minority' cultural practitioners, arguably because they had, to date, been forced to operate from the margins of the creative industries and of British political life.[5] The impact of My Beautiful Laundrette (Stephen Frears, 1985) exemplified perfectly the potential gains at stake here, not only for audiences but also for critics and the academic community.

Onscreen, Channel 4 produced dedicated slots and structures to cater for black and Asian audiences. With minority programming uniquely built into its structure, organization and output was explicitly linked. By the late 1980s, Channel 4 was airing a number of 'black programmes' which were often staffed from producer level downwards by black media workers. Over the years, it was primarily factually-based productions such as Eastern Eye (1982-85), Black on Black (1983-85), The Bandung File (1985-91), Black Bag (1991-97) and Devil's Advocate (1992-96) that became the leading examples of black programming, focusing on issues that were seen to be directly relevant for black 
and Asian communities. And the emphasis on developing black British production talent meant that there were breakthroughs in other genres: for example, through the popular comedy series Desmond's (1988-94) new writers, many of them women, were introduced to the industry.

It is easy to summarize such breakthroughs in simple and glowing terms. But there were of course also specific politics and problems involved. The relative autocracy of some of the Multicultural Programmes Department's commissioning editors was attacked. The gradual relocation of minority programming from peak-time to graveyard slots was criticized. And partly because of the high expectations from minority practitioners, Channel 4's recruitment practices were widely criticized for not doing enough, and for sidestepping both new and existing black talent. By 1990, largely as a result of financial strain within a number of public arts institutions, the revenue funding of independent film and video workshops had virtually ceased. The 1990 Broadcasting Act and a change to Channel 4's funding arrangement in 1993 were significant milestones in determining future priorities. Concurrently the channel, now under the direction of Michael Grade, was faced with the emergence of increasing competition, lighter-touch regulation and technological advances, and began to show different kinds of investment towards more obvious ratings-pullers such as US imports. What was once mainstream began to be squeezed out to the margins as some areas of investment faced more pressure than others.

We can locate the critical turn away from the idea of multiculturalism in the mid 1990s. Essentially this involved a break from a race politics underpinned by a quantitative or socalled 'politically correct' response to a multicultural society to one that positions 'cultural diversity' as a qualitative mindset that depends on 'common sense' - not something that can simply or easily be enforced or implemented through targets or positive action measures if it wants to be consequential and champion its goals. Discursive shifts within public service broadcasting were symptomatic of this wider change. Media policy in general began to shift towards a more mainstream and less nuanced definition of 'multiculturalism' as 'cultural diversity'. This policy shift also later coincided with the public focus on 'institutional racism', following the 1999 Macpherson Report,[6] a milestone which appeared to trigger, at least on the surface, a surge of proactive responses in favour of cultural diversity in the arts and media (rather than, it should be noted, against racism). In 2000, for example, a network of UK broadcasters including Channel 4 established the Cultural Diversity Network, designed to promote cultural diversity on and off screen, although its impact in significantly addressing the issue is uncertain.

The most illustrative consequence of the redistributive project occurred when the decision was taken in 2002 that Channel 4's Multicultural Programmes Department should close. Channel 4 now repositioned multicultural representations as part of a broader diversity agenda in which ethnic diversity was just one component.[7] This supported a broader ethos of viewers as 'viewers' rather than viewers as 'anyone-inparticular'. It was suggested that, like British society, Channel 4 had 'moved on' and that the real future of ethnic minority representation was in mainstream programming. The reorganization of support, or arguably disinvestment, was almost certainly a decision based more on mounting commercial pressure, as the multichannel system boomed, than on cultural intelligence. However, this was not the way it was publicly described. In 2001, Michael Jackson, who had been Channel 4's chief executive since 1997, explained the rationale for the new approach: Twenty years ago television didn't honestly reflect society. Channel 4 was launched in 1982 to give a voice to those who were underrepresented on the three channels that then existed. In 2001 the 'minorities' of those times have been assimilated into the mainstream of society.[8] Once a pioneer in introducing the idea of antiracism into the liberal project, the channel now assumed a more customary position, using the language of integration. Of course, in many ways, specialist minority programming did work against public service broadcasting principles of universality. This approach is always in tension with, on the one hand, the 'struggle 
for recognition' and, on the other, the critique from neoliberalism that it represents a drag on the market. It is open to the idea that there is no payoff from an apparent engagement of political debate into structural questions of redistribution in the economic sphere. It also calls into question the idea that 'difference' can be the basis for effective political agency.

However, the rationale given by Jackson was far less theoretical. The closure of the Multicultural Department signalled, for better or worse, the offcial declaration of postmulticulturalism within public service broadcasting. On a practical level, the nuances of this shift removed certain requirements for the quantity and source of minority-based output, something that the Multicultural Programmes Department was designed to help systematize. In 2002, the new head of Channel 4, Mark Thompson, spoke in his MacTaggart Lecture about a new kind of public service and about trusting individual commissioning editors to 'ensure that the programme-makers they use are really representative of the culturally diverse country we serve'. In that year's 'Statement of Promises', the function of the Multicultural Department was still being publicly promoted: 'The Multicultural Department has a specific remit to be ahead of the curve and interrogate multicultural Britain in unexpected ways.'

The tangible outputs stemming from this new response to Britain's cultural diversity were, however, difficult to discern onscreen. Therefore, the closure might be understood as a symbolic gesture and certainly more expedient and consequential than Channel 4's assimilationist and 'common-sense' rhetoric would have its public believe. The new proposal, that integration is good and segregation is bad, continues to work today in line with broader political-cultural philosophies around multiculturalism. This is underpinned by an implicit assumption not just that social equality has basically been achieved but also that multicultural agendas have done more damage than good. In 2005, Trevor Phillips, then chairman of the Commission for Racial Equality, predicted that Britain was 'sleepwalking into segregation'. Phillips, who at the start of his career had worked as a television researcher on London Weekend Television's black factual programme Skin (1980), argued that decades of multicultural policies had served to deepen racial divisions and increase tensions.

This sea-change has been usefully outlined in a more general context by Arun Kundnani in his essay 'How liberals lost their anti-racism'.[9] Here, Kundnani argues that many former left-leaning liberals have now shifted to the right, and that today even the updated liberal ideal of 'cultural diversity in an atmosphere of mutual tolerance' is regarded as too soft and not interventionist enough by mainstream liberals. And yet, we know that in British society social inequality persists, as do claims from ethnic minorities for 'better representation'. And this is in spite, not because, of decades of multicultural policies. Within British society popular narratives around 'asylum seekers', 'black gun crime', 'freedom of speech', the 'clash of civilizations' and most of all 'the war on terror', define today's racialized agenda. 9/11 intensified the retort against multiculturalism; it also interrupted the beginning of the movement towards cultural diversity and recognition of 'institutional racism' that had, until then, been gaining momentum. For many, these tropes are precisely the reasons that validate our current post-multicultural sensibility, because they symbolize the problem with 'difference' and anything ranging from the failures to the dangers of liberal multiculturalism. They have sustained a national preoccupation with evaluating the merits of multiculturalism and suggest that questions of belonging and difference in our society are still heavily dependent on themes of cultural identity and, indeed, 'race'. Such thinking now occupies the middle ground, making Channel 4's revised ethos in the early-to-mid 2000s very much 'of the moment' - acceptable and perhaps even inevitable. It demonstrates how the 'loss' of antiracism has been institutionalized.

As the only UK terrestrial channel to have been established with multicultural programming embedded as part of its infrastructure and core practice, the impact of these new social philosophies on broadcast media and, specifically, the closure of the 
specialist department has, remarkably, passed with very little public comment or introspection. At an event held at Channel 4 in 2007 to mark both its twenty-fifth anniversary and Black History Month, 'To Black and beyond: the Black image on TV', these changes within Channel 4 largely went unacknowledged, but the same general problems of access and racially-coded representation were seen to persist. There was a certain kind of cultural amnesia at work - a lack of reference to Channel 4's important history in relation to ethnic minorities - which seemed to be characteristic both of broader patterns of forgetting with regard to black history and the legacy of the idea of what the channel still stands for.

At the event, Janey Walker, Channel 4's Managing Editor for Commissioning, suggested that there is a 'rose-tinted view' of Channel 4's Multicultural Programmes Department and that the main reason it closed was because of the high level of complaints from minority producers that their access to other departments such as Drama or Comedy, were blocked because they were always directed to the Multicultural Programmes Department. This argument calls into question how a holistic commitment to cultural diversity might be interpreted within and across the channel and also that each commissioning editor will necessarily 'instinctively' take on board the responsibility to platform multiculturalism as Thompson had proposed in 2002.

Indeed, in March 2008, these assertions were apparently contradicted when Channel 4 announced that as part of its major review of its public service role, it was going to work on: reinvigorating its connection with minority audiences, including appointing a new Head of Diversity, assigning a commissioning editor specific responsibility for multicultural programmes, with a ring-fenced budget and slots at $9 \mathrm{pm}$ and $10 \mathrm{pm}$, and doubling the budget for the commissioning team's diversity placement scheme.[10] Significantly, these new initiatives have occurred within the framework of an ever-more commercially-oriented media environment within which Channel 4 is under extreme pressure, as indicated in Ofcom's second public service broadcasting review in 2008. Channel 4's current public-service drive is entwined with its renewed diversity emphasis (which arguably sits at the heart of a public service ethos). It is an important aspect of the organization's strategy to attract monies in a digital age in which the era of traditional public service broadcasting is fast eroding. Conspicuously, the BBC also announced a renewed drive in 2008, which involves the broadcaster spending $£ 750,000$ on strategies to fill more top positions with ethnic minorities and includes a mentoring and development programme over three years. The fruits of such strategic planning are, at the time of writing, yet to be seen.

The bigger picture also means that, largely because of timing, ethnic minorities have been incorporated, in different ways, as a more general part of the mainstream. Although the use of Jackson's definitive claim that minorities have been 'assimilated into the mainstream' as the raison d'être for organizational change is problematic, by the late 1990s black and Asian communities had become more established within British society. In broad terms, there was an emerging and confident third generation and a bigger ethnic minority general workforce in parts of the creative industries. The 'old ethnics', once at the vanguard of struggles for media access and Channel 4's diversity concerns, were now positioning themselves as the 'new diasporas', engaging with cable and satellite services more than any other part of the UK population. The transnationalization of broadcasting had begun to have a profound effect on Britain's ethnic minority audiences who seemed, in fact, to be very keen to be positioned as viewers from 'somewhere-in-particular'.

Meanwhile, the general circuit of Channel 4's onscreen representation, from newsreaders to soap characters to participants in lifestyle shows, now gives the appearance of a more ethnically diverse Britain. On the whole, the demise of specialist ethnic programming did in fact coincide with a more general inclusion of ethnic minority representation in everyday output. But far from being the result of well-planned policy, this transition into the mainstream is largely down to simultaneous changes that have happened within the 
industry. Specifically, the rise in aspirational lifestyle programming in the 1990s and its migration from daytime programming to the weekday early-evening schedules, most notably on Channel 4, was the primary route through which black and Asian images became 'mainstreamed' and more commonplace for a broader range of the viewing public. As Charlotte Brunsdon notes: 'through their choice of participants, programmes such as these make a considerable contribution to changing ideas of what it is to be British'. [11]

Traditional notions of authored access found in the 1970s and 1980s [12] were reinterpreted in the form of docu-soaps, video diaries, makeover and lifestyle shows, giving a highly public platform to a larger range of cultural and social 'types'. In addition, because the reality genre is relatively unscripted compared with non-reality or narrative television, it largely escapes serious accusations of misrepresentation, lack of authenticity or stereotyping - all criticisms that Channel 4 producers, editors and scriptwriters had long wrestled with when considering how to represent ethnic minorities in the 'right' ways. Whilst what Brunsdon calls the 'pluralling up' [13] in these genres achieves the demographic project of boosting the numbers, the fact that this has occurred in reliable (and often proven global) formats that are almost guaranteed ratings-winners is important. When it comes to the market, inclusion of ethnic minorities in reliable formats is both low risk and has the added bonus of meeting cultural objectives.

But in a moment that is seeing intense scrutiny of certain approaches to some programme-making, the question of media parity now, more than ever, has to be understood within the context of a range of concerns, both commercial and ethical. 2007's Celebrity Big Brother beautifully demonstrated the tricky balancing act that might be involved here, and how (Channel 4's) 'reality entertainment' can, in fact, forcefully clash with how ethnicity and race are managed. When the Bollywood actress Shilpa Shetty was bullied and racially taunted by fellow 'celebrity' housemates including Jade Goody, Channel 4's bungling treatment of the race row raised public concern about where exactly it draws the boundaries of commercial and political expediency. Celebrity Big Brother foregrounded precisely these issues around ethnic minority representation, communication rights and the politics of recognition. Channel 4's non-intervention as the gang bullying intensified was defended by an alibi of genre-etiquette; that is, the producers could not be seen to 'intrude' and spoil the natural order of things in the house. Of course, the real codes of reality television demand that it is never left fully uninterrupted by the manoeuvring of those in the business of programme-making in order to generate interest, by devising tasks, editing strategically, interviewing provocatively, and so on.

The real story here is not about Shilpa versus Jade, or the question of whether the abuse is tantamount to racism or bullying, it is about Channel 4 and the public. The damning Ofcom verdict ruled, amongst other things, that Channel 4 had broken its broadcasting code by not declaring knowledge of (unbroadcast) racist footage, including film showing some of the Celebrity Big Brother housemates using the word 'Paki' in a limerick. Once recognized as championing ethnic diversity, Channel 4 mediated conflict in order to maximize ratings, and as Tessa J owell (the then Culture, Media and Sport Secretary) put it, gave audiences little more than 'racism being presented as entertainment'.[14] The response to the reality series, as Channel 4 found out when unprecedented complaints were made to Ofcom, served as a sharp reminder that audiences have communication rights and cultural sensitivities that need to be recognized when tasked with serving a diverse public. Channel 4's chief executive at the time, Andy Duncan, admitted the channel had failed to see the viewers as 'real people, rather than ratings'; [15] a candid comment that is suggestive of the reconceptualization of the television 'citizen' as a television 'consumer'.

Channel 4 is at a critical juncture with respect to these concerns. Its scheduling of the heavily publicized and discussed landmark two-part drama, Britz (2007) in its twenty- 
fifth anniversary week cast the spotlight on some of the intricacies involved. Based around a British Asian Muslim sister and brother who respectively become a terrorist and join MI5 to protect British security, Britz was provocatively marketed with an image of the siblings and the strapline 'Whose side are you on?'. On the one hand, Britz can be seen to follow and exacerbate recurrent tabloid themes around Islam: suicide bombers, the rise of terrorism, British Jihadism. On the other, it offers a political commentary on British anti-terror legislation and addresses the issues from an alternative starting point. Its high-budget production values make a mockery of the budgets involved in early black programming, and as a drama/thriller it marks a genre breakthrough in terms of where we still typically tend to see British Asians on television. Questions about the politics of its authorship have been raised because the drama was directed by a white man, Peter Korminsky, even though his track record would suggest he helped to produce an exhilarating piece of television drama. But if one takes into account the context of Channel 4's dwindling investment in black and Asian creative producers, the concerns are entirely valid.

When thinking about developments onscreen, it is clear that Asians in particular have recently become more visible, whilst Africans and Caribbeans have been notable for their growing absence, a verifiable shift from a decade ago when the reverse could be said to be the case. The reasons for the emergence of the disparity between the amount of black and Asian representation can largely be attributed to an increased focus on 'Asiannness' in the popular imagination; an interest fuelled not just by the 'positive' commodification of a globalized, Bollywood-influenced South Asian popular culture, but also by the 'negative' preoccupation with Islam. This is not to liken Channel 4's programming of Islam to a tabloid agenda, but the channel has piggy-backed on the popular interest in Islam and its associated discourse at a time when British Muslims are already such a substantial source of media content, and only in particular ways.[16]

The issues that have been outlined here are especially timely insofar as changes within the ecology of public service broadcasting are having an important impact on the delivery and content of minority programming. Three sets of concerns will help to conclude.

Firstly, what future opportunities exist for ethnic minorities to be granted their communication rights by Channel 4 ? This involves investigating how public policy works in conjunction with competitive market forces and cultural demands. It requires us to look beyond onscreen representation to consider the critical relationship between two trajectories: the threat to traditional public service delivery and the appetite of ethnic groups for 'better representation'. Specifically, one might ask how the tension between changes in the mediascape and in the politics of recognition is reflected in the structuring and regulation of Channel 4 with regards to ethnic representation in a maturing postcolonial Britain. The key challenge here is to reduce the gap between the importance ethnic minority viewers place on trust in Channel 4 and their satisfaction with its delivery.

Secondly, we need to consider how the politics of difference is recognized and accommodated within a media culture which aspires to 'sameness'. Ethnic and racial consciousness is an emergent property of particular sorts of social relations connecting issues of citizenship, value pluralism and the role of community, not least in the ways ethnic minority groups generate media practices. But as broadcast media in general becomes more divergent and at the same time more cloned, how responsible is Channel 4 for taking on a more distinctive public service approach to ethnic minority representation?

Finally, we should analyze the creative basis of ethnic minority production. For example, does a black programme-maker producing a documentary in a dedicated black programme series, have, as was felt by many who worked in specialist departments, more freedom of creative and/or political expression when they are not working in and for a mainstream series with other sets of expectations? What are the artistic 
implications of moving from the margins to the centre in this way? This is a question premissed on issues of innovation and production (culturally diverse expression) which have been forcefully elided by the heavily policy-oriented narrative (cultural diversity policy) in this area.

'Black' is simply not on the agenda in the same way that it was when the channel first started, but then much has changed over the past twenty-five years and the shifts need to be read in context. Today, all commissioning teams and independent producers have new responsibilities for ensuring that Channel 4 reflects a modern, vibrant, multicultural Britain. But this is not a transparent agreement and certainly not one which can be held to account by the public in clear or precise ways. Lessons from the past, more open consultation with its many publics, and recognition of each viewer as a citizen, not just a consumer, may help work through some of the issues of rights, responsibilities and creativity outlined here.

\section{Footnotes}

[1] Stephen Lambert, Television with a Difference (London: British Film Institute, 1982), p. 100.

[2] In 2006 there was widespread agreement amongst a range of public political figures that the idea of multiculturalism was outdated. Tony Blair, then Prime Minister, argued that: 'The right to be different. The duty to integrate. That is what being British means.' Ruth Kelly, the Communities Secretary, said: 'We have moved from a period of near uniform consensus on the value of multiculturalism to one where we can encourage that debate by questioning whether it is encouraging separateness.'

[3] David Bailey and Stuart Hall, 'Critical decade: black British photography in the 80s', Ten.8, vol. 2, no. 3 (1992), p. 7.

[4] See Alkarim Jivani, 'Channelling the past', Sight and Sound, vol. 17, no. 12 (2007).

[5] See Kobena Mercer (ed.), Black Film, British Cinema, ICA Documents, no. 7 (London: Institute of Contemporary Arts, 1988).

[6] A report resulting from an inquiry into the police's handling of the murder of black teenager Stephen Lawrence. URL: http://www. archive. official-

documents. co.uk/document/cm42/4262/4262.htm [accessed 21 J une 2008].

[7] In Channel 4's 2007 Statement of Programme Policy, 'Cultural and other diversity' is located in the 'Additional Matters' section, p. 23.

[8] Michael J ackson, 'The fourth way', The Observer, 29 July 2001.

[9] Arun Kundnani, 'How liberals lost their anti-racism,' Institute of Race Relations, 3 October 2007. URL: http://www.irr.org.uk/2007/october/ha000008.html [accessed 21 June 2008].

[10] Quoted in Ofcom, Second Public Service Broadcasting Review Phase One: the Digital Opportunity (2008), p. 106. URL:

http://www. ofcom.org.uk/consult/condocs/psb2_1/ [accessed 21 J une 2008].

[11] Charlotte Brunsdon, 'Lifestyling Britain: the 8-9 slot on British television', International Journal of Cultural Studies, vol. 6, no. 1 (2003), p. 13.

[12] See Sarita Malik, Representing Black Britain: Black and Asian Images on Television (London: Sage, 2002). 
[13] Ibid., p. 18.

[14] J owell, quoted in The Guardian, 19 January 2007, p. 1.

[15] Duncan, quoted in The Guardian, 28 May 2007, p. 1.

[16] See 'The search for common ground: Muslims, non-Muslims and the UK media', Greater London Authority, November 2007. URL:

http://www. Iondon.gov.uk/mayor/equalities/docs/commonground_report.pdf [accessed 21 J une 2008]. 